\title{
Organization of AMPA Receptor Subunits at a Glutamate Synapse: A Quantitative Immunogold Analysis of Hair Cell Synapses in the Rat Organ of Corti
}

\author{
Atsushi Matsubara, ${ }^{1,2}$ Jon H. Laake, ${ }^{1}$ Svend Davanger, ${ }^{1}$ Shin-ichi Usami, ${ }^{2}$ and Ole P. Ottersen ${ }^{1}$ \\ ${ }^{1}$ Department of Anatomy, Institute of Basic Medical Sciences, University of Oslo, P.O. Box 1105 Blindern, N-0317 Os/o, \\ Norway, and 2Department of Otorhinolaryngology, Hirosaki University School of Medicine, Hirosaki, 036 Japan
}

\begin{abstract}
Sensitive and high-resolution immunocytochemical procedures were used to investigate the spatial organization of AMPA receptor subunits (GluR1-4) at the synapse between the inner hair cells and the afferent dendrites in the rat organ of Corti. This is a synapse with special functional properties and with a presynaptic dense body that defines the center of the synapse and facilitates its morphometric analysis. A quantitative postembedding immunocytochemical analysis was performed on specimens that had been embedded in a metachrylate resin at low temperature after freeze substitution. Single- and double-labeling procedures indicated that GluR2/3 and GluR4 subunits were colocalized throughout the postsynaptic density, with a maximum distance of $300 \mathrm{~nm}$ from the presynaptic body
\end{abstract}

and with higher concentrations peripherally than centrally. No receptor immunolabeling was found at extrasynaptic membranes, but some GluR4 subunits appeared to be expressed presynaptically. The synapses between outer hair cells and afferent dendrites were devoid of labeling. The present data indicate that AMPA receptor subunits are inserted into the postsynaptic membrane in a very precise manner and that their density increases on moving away from the center of the synapse.

Key words: AMPA; pre- and postsynaptic receptors; immunocytochemistry; immunogold; silver enhancement; organ of Corti; rat
The issue of how glutamate receptors and AMPA receptors in particular are arranged in the postsynaptic membrane is central to our understanding of synaptic transmission and synaptic plasticity. For example, it has been suggested that AMPA receptors are organized in discrete clusters that may limit the quantal size and that the formation of new receptor clusters, combined with a structural reorganization of the synapse, may be a critical step in the development of long-term potentiation (Edwards, 1995a,b).

The present investigation exploits quantitative and highly sensitive immunocytochemical procedures to reveal the detailed distribution of AMPA receptors [GluR1-4 according to the terminology of Boulter et al. (1990); GluRA-D according to Keinänen et al. (1990)] at the synapse between inner hair cells and afferent dendrites in the organ of Corti. This synapse has the advantage compared with hippocampal and other central synapses of having a presynaptic dense body (Hashimoto et al., 1990; Friedmann and Ballantyne, 1984) that defines the center of the synapse and the preferential site of exocytotic release. This feature facilitates morphological analysis and allows data to be obtained that may help construct useful models of synaptic transmission.

The specific aim of the present investigation was to reveal how the different AMPA receptor subunits are distributed along the

\footnotetext{
Received Feb. 29, 1996; revised April 18, 1996; accepted April 24, 1996.

This work was supported by the Ministry of Education of Japan, the Norwegian Research Council, J. E. Isberg's Fund, and the European Union Biomed program. We thank Dr. R. J. Wenthold for his generous gift of antibodies, B. Riber, K. M. Gujord, G. Lothe, and T. Nordby for technical assistance, and Drs. J. StormMathisen, H. Ohmori, T. Lømo, and J. Storm for helpful comments. We also extend our thanks to Dr. Eva Skovlund for help with the statistics.

Correspondence should be addressed to Dr. Ole Petter Ottersen, Department of Anatomy, Institute of Basic Medical Sciences, University of Oslo, P.O. Box 1105 Blindern, N-0317 Oslo, Norway.

Copyright (C) 1996 Society for Neuroscience $0270-6474 / 96 / 164457-11 \$ 05.00 / 0$
}

mediolateral extent of the postsynaptic density and along the radial axis, i.e., perpendicular to the postsynaptic membrane. An attempt was also made to resolve to what extent the AMPA receptors occur at extrasynaptic sites.

\section{MATERIALS AND METHODS}

Tissue preparation. Ten Wistar rats (250-300 gm) were deeply anesthetized with sodium pentobarbital $(50 \mathrm{mg} / \mathrm{kg}$ ), and $1 \mathrm{ml}$ of fixative (see below) was injected into the cochlea according to the perilymphatic perfusion method (Wersäll, 1956; Anniko and Lundquist, 1980). Subsequently, the animals were perfused transcardially with $2 \%$ dextran (MW $70,000)$ in $0.1 \mathrm{M}$ phosphate buffer $\left(\mathrm{PB} ; \mathrm{pH} 7.4,4^{\circ} \mathrm{C}, 15 \mathrm{sec}\right.$ ) followed by fixative (room temperature, $50 \mathrm{ml} / \mathrm{min}$ for $10-20 \mathrm{~min}$ ). Four different mixtures of fixative (all in $0.1 \mathrm{M} \mathrm{PB}, \mathrm{pH} 7.4$ ) were used: No. 1, $4 \%$ formaldehyde (depolymerized from paraformaldehyde) and $0.1 \%$ glutaraldehyde; No. 2, $4 \%$ formaldehyde and $0.5 \%$ glutaraldehyde; No. 3, $4 \%$ formaldehyde, $0.1 \%$ glutaraldehyde, and $0.2 \%$ picric acid; No. $4,1 \%$ formaldehyde and $2.5 \%$ glutaraldehyde.

The number of ears treated with the different fixatives were 10, 4, 4, and 2, respectively. After perfusion, the temporal bones were removed and immersed in the same fixative $\left(6-8 \mathrm{hr}, 4^{\circ} \mathrm{C}\right)$ and then rinsed in $0.1 \mathrm{M}$ $\mathrm{PB}$ (overnight, $4^{\circ} \mathrm{C}$ ). The organ of Corti was carefully dissected from the temporal bone. Freeze substitution and low-temperature embedding of the specimens in a metachrylate resin were performed (van Lookeren Campagne et al., 1991; Hjelle et al., 1994; Chaudhry et al., 1995). Briefly, the specimens were cryoprotected by immersion in graded concentrations of glycerol $(10,20$, and $30 \%)$ in $\mathrm{PB}$ and plunged rapidly into liquid propane cooled by liquid nitrogen $\left(-190^{\circ} \mathrm{C}\right)$ in a cryofixation unit $\mathrm{KF} 80$ (Reichert, Vienna, Austria). The samples were immersed in $0.5 \%$ uranyl acetate dissolved in anhydrous methanol $\left(-90^{\circ} \mathrm{C}, 24 \mathrm{hr}\right)$ in a cryosubstitution unit (AFS; Reichert). The temperature was raised in steps of $4^{\circ} \mathrm{C} / \mathrm{hr}$ from $-90^{\circ} \mathrm{C}$ to $-45^{\circ} \mathrm{C}$. The samples were washed three times with anhydrous methanol and infiltrated with Lowicryl HM20 resin (Chemische Werke Lowi, Waldkraiburg, Germany) at $-45^{\circ} \mathrm{C}$ with a progressive increase in the ratio of resin to methanol. Polymerization was performed with ultraviolet light $(360 \mathrm{~nm})$ for $48 \mathrm{hr}$.

We also used an osmium-free method of epoxy resin embedding 
essentially as described previously (Phend et al., 1995). Specimens (fixative No. 4) were sequentially incubated in $1 \%$ tannic acid (Fluka, Buchs, Switzerland), $1 \%$ uranyl acetate, and $0.5 \%$ platinum chloride (Fluka), all in $0.1 \mathrm{M}$ maleate buffer, $\mathrm{pH}$ 6.0. Then they were immersed in ethanol followed by $1 \%$ p-phenylenediamine (Sigma, St. Louis, MO) in ethanol. The specimens were dehydrated and embedded in Durcupan (ACM, Fluka).

Sections of the cerebellum and hippocampus were used as positive controls. The sections were obtained from the same animals that were subjected to perilymphatic perfusion and were incubated in the same drops of immunoreagents as the cochlear sections.

Postembedding immunocytochemistry. Two different procedures were used for postembedding immunocytochemistry. One was based on $15 \mathrm{~nm}$ gold-coupled goat anti-rabbit IgG (GAR15, Nanoprobes, Stony Brook, NY) as secondary antibody (Hjelle et al., 1994, modified from van Lookeren Campagne et al., 1991), and the other was based on $1.4 \mathrm{~nm}$ gold-coupled goat anti-rabbit Fab' fragments (Nanogold, Nanoprobes) followed by silver enhancement. For both procedures, ultrathin sections (Lowicryl or Durcupan) were treated with a saturated solution of $\mathrm{NaOH}$ in absolute ethanol $(2-3 \mathrm{sec})$, rinsed, and incubated in the following solutions at room temperature: (1) $0.1 \%$ sodium borohydride and $50 \mathrm{~mm}$ glycine in Tris-buffered saline containing $0.1 \%$ Triton X-100 (TBST) (10 min); (2) $2 \%$ human serum albumin (HSA) in TBST (10 min); (3) primary antibodies against GluR1, GluR2/3, or GluR4 (concentration $1-2 \mu \mathrm{g} / \mathrm{ml}$, kindly provided by Dr. R. J. Wenthold) in TBST containing $2 \%$ HSA (2 hr); (4) $2 \%$ HSA in TBST (10 min); (5) secondary goldcoupled Fab' or IgG diluted 1:50 in the TBST containing 2\% HSA and polyethyleneglycol $(5 \mathrm{mg} / \mathrm{ml}, 2 \mathrm{hr})$. For silver enhancement, the sections were finally incubated in HQ Silver (Nanoprobes) for 3-4 min. Systematic variation of the $\mathrm{NaCl}$ concentration in the buffer (steps 2-5) revealed a maximum labeling efficiency at $0.05 \mathrm{M}$. The pretreatment of the sections with $\mathrm{NaOH} /$ ethanol was essential for a high sensitivity, whereas the choice of fixative (see above) was less important, at least for the inner ear tissue.

Postembedding immunogold double labeling and immunocytochemical controls. Double labeling of GluR2/3 and GluR4 or GluR2/3 and glutamate was performed as described previously (Ottersen et al., 1992) using formaldehyde vapor treatment to avoid interference between the two sequential incubations (Wang and Larsson, 1985). For GluR2/3 and glutamate immunolabeling, the receptor antibodies were used first (visualized by $1.4 \mathrm{~nm}$ gold and silver enhancement) followed by the glutamate antibody (No. 607; diluted 1:2000 and visualized by $30 \mathrm{~nm}$ gold particles) (Ericson et al., 1995). For GluR2/3 and GluR4 immunolabeling, 30 and $15 \mathrm{~nm}$ gold particles were used.

Control experiments included omission of the primary antibodies and absorption with antigen (for antiserum No. 607) (Ericson et al., 1995). Both types of treatment abolished the labeling. All antisera have been thoroughly characterized. The GluR1, GluR2/3, and GluR4 antibodies react selectively with the respective receptor subunits (Petralia and Wenthold, 1992; Wenthold et al., 1992), whereas the glutamate antibody has been shown to recognize glutamate but not other compounds, including the structurally related amino acids aspartate and glutamine (Ericson et al., 1995). Western blot analysis of the organ of Corti has revealed bands of appropriate molecular weights for GluR2/3 and GluR4 (Kuriyama et al., 1994).

For quantitative analysis, the distance between the reference line (periphery of antigen-containing body or outer leaflet of the postsynaptic membrane) to the centers of gold particles was measured manually at $83,000 \times$ magnification. The antigen-containing bodies (Fig. 7) were prepared as described (Ottersen, 1987), sectioned, and incubated with the tissue sections (see legend to Fig. 7 for details).

\section{RESULTS}

\section{Ultrastructure}

The tissue preservation was assessed in sections that had been counterstained with uranyl acetate and lead citrate. The mixture of $4 \%$ formaldehyde and $0.5 \%$ glutaraldehyde (Fig. 1) gave a better ultrastructural preservation than the mixture containing $0.1 \%$ glutaraldehyde only. The former fixative, therefore, was used for most of the preparations.

\section{GluR2/3}

The antibody used (Ab 25) (Wenthold et al., 1992) recognizes the GluR2 and the GluR3 subunits. In a first series of experiments, we sought to obtain a maximum immunolabeling efficiency by using secondary antibodies coupled to very small $(1.4 \mathrm{~nm})$ gold particles. The particles were made visible by silver enhancement. This procedure gave up to 60 particles per profile of synaptic density on the afferent fibers contacting the inner hair cells (Fig. $2 A$ ). This particle density is comparable to and even exceeds that found on the postsynaptic membrane of the parallel fiber to Purkinje cell synapses in the cerebellum (Fig. $2 B$; same incubation). In the inner hair cell synapse, the gold particles were distributed along the entire extent of the postsynaptic density with no gaps that could point to the existence of discrete clusters. The particles adhered closely to the postsynaptic membrane with a spread of $<35 \mathrm{~nm}$ along the axis perpendicular to the membrane (hereafter called the radial axis). Only in a few cases were scattered particles observed lateral to the postsynaptic density, and the occurrence of particles in the presynaptic element (Fig. $2 A$ ) was not a consistent phenomenon.

By double labeling it could be shown that the hair cell bases facing GluR2/3 receptors contained high levels of glutamate-like immunoreactivity (Fig. 2C). Some gold particles signaling glutamate were associated with synaptic vesicles, whereas others decorated mitochondrial profiles. This is similar to the distribution of glutamate-like immunoreactivity in central synapses (Somogyi et al., 1986; Ji et al., 1991). The relatively weak labeling in the postsynaptic element is likely to reflect the ubiquitous metabolic pool of glutamate (Ottersen et al., 1992) and/or postsynaptic glutamate uptake (Rothstein et al., 1994).

For further analysis of the GluR2/3 distribution, we used secondary antibodies coupled to $15 \mathrm{~nm}$ colloidal gold particles (Fig. 3 ). Because of their uniform size and distinctness, these particles were better suited to quantitative studies than the silver-enhanced ones, which tended to coalesce. In agreement with the observations based on the silver enhancement procedure, the $15 \mathrm{~nm}$ particles were associated with peripheral as well as central parts of the postsynaptic density (Fig. $3 A, B$ ), similar to the situation in the glutamatergic CNS pathways that were used for comparison (Fig. $3 D$ ). Most of the gold particles were directly superimposed on the postsynaptic membrane or near its external or cytoplasmic surface (see below for quantitative analysis).

\section{GluR4}

The afferent fibers contacting the inner hair cells also displayed gold particles signaling the presence of GluR4, recognized by an antibody that is selective for this subunit ( $\mathrm{Ab} 22$ ) (Wenthold et al., 1992). Although the tangential distribution of these particles along the postsynaptic density was similar to that of the particles representing GluR2/3, their radial distribution was different. Thus, a minor proportion of the particles appeared to be associated more closely with the presynaptic membrane than with the postsynaptic one (Fig. 4). This pattern was confirmed by quantitative analysis (see below) and in silver-enhanced preparations (not shown).

The GluR4 antiserum produced very weak labeling outside the synaptic region. The labeling pattern obtained in freezesubstituted material fixed by a relatively low glutaraldehyde concentration $(0.5 \%$; Fig. $4 A, C, D)$ was reproduced in material that was fixed by a higher percentage of glutaraldehyde $(2.5 \%)$ and prepared according to a different protocol (Phend et al., 1995) based on the use of an epoxy resin (Fig. 4B). 


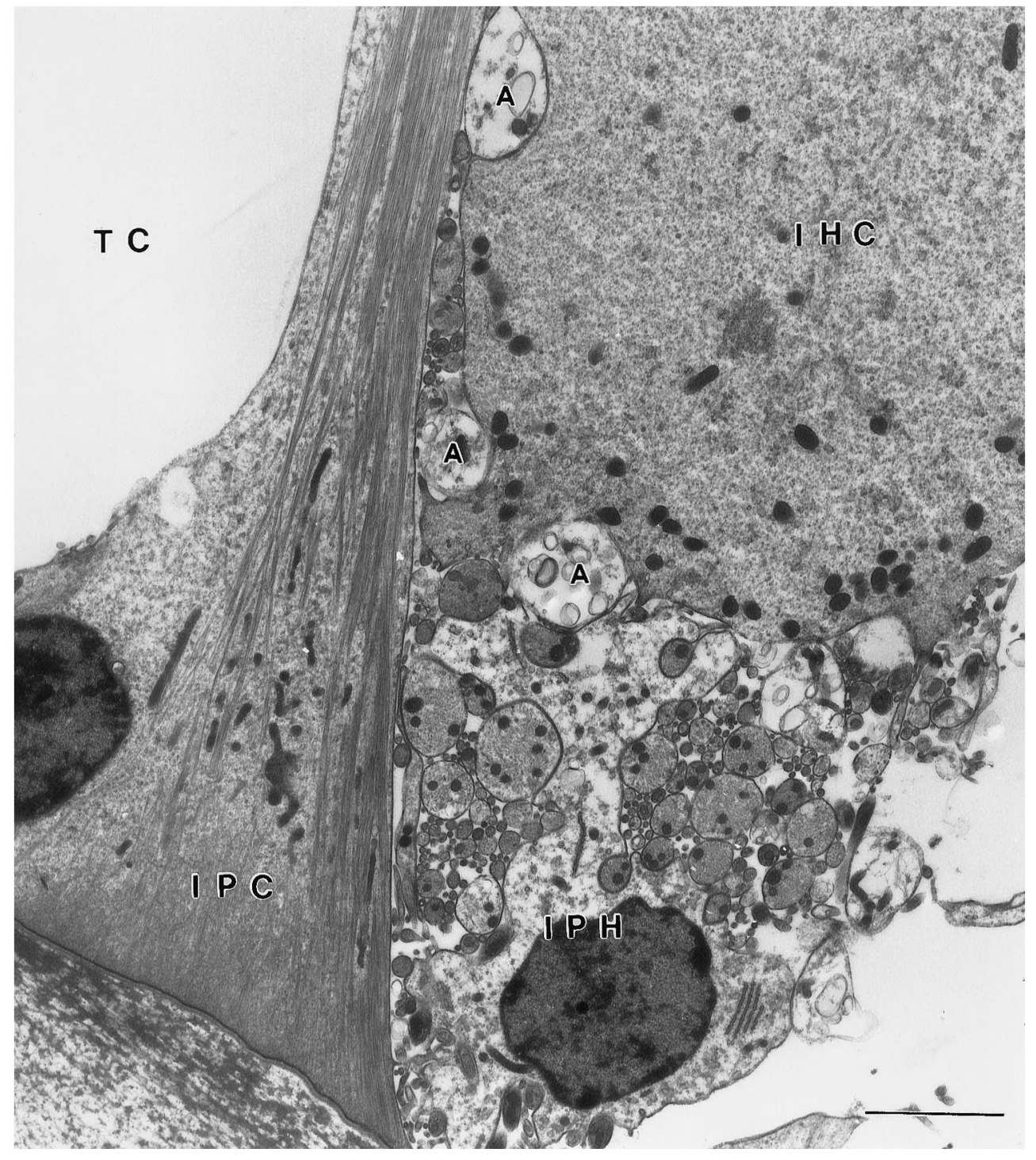

Figure 1. Electron micrograph of freeze-substituted specimen of the organ of Corti showing the synaptic region of the inner hair cell $(I H C)$. The section was counterstained with uranyl acetate and lead citrate. The ultrastructure of the IHC and afferent nerve endings $(A)$ in contact with the cell body were well preserved. IPC, Inner pillar cell; IPH, inner phalangeal cell; $T C$, tunnel of Corti. Fixative No. 2. Scale bar, $3.0 \mu \mathrm{m}$.

\section{Quantitative comparison of the distributions of GluR2/3 and GluR4}

As noted above, the impression gained by visual examination of the electron micrographs was that GluR2/3 and GluR4 were differentially distributed along the radial axis (i.e., perpendicular to the postsynaptic density). This was confirmed by quantitative analysis (Fig. 5). Whereas the distribution of gold particles representing GluR2/3 displayed a single distinct peak (positioned 5 $\mathrm{nm}$ postsynaptic to the outer leaflet of the postsynaptic membrane), the corresponding histogram for GluR4 was broader and extended further in the presynaptic direction. The difference between the two distributions was validated statistically (Table 1). The distance between the two peaks in the histogram for GluR4 was $20-25 \mathrm{~nm}$, compared with a mean width of the synaptic cleft of $14.9 \mathrm{~nm}$ (estimated from 10 synapses).

The analysis of the tangential distribution of particles was based exclusively on the relatively few synapses that exhibited a distinct synaptic body in the plane of section. This served to define the center of the synapse (see legend to Fig. 6). With both antibodies, the labeling extended up to $300 \mathrm{~nm}$ from the center thus defined. The particle density was lower in the central part of the postsynaptic membrane than in the lateral part (Fig. 6).
To facilitate the interpretation of the histograms in Figures 5 and 6, we determined how accurately the epitopes could be localized under the present experimental conditions. To this end, we analyzed the distribution of gold particles associated with discrete bodies of a test antigen (Fig. 7A) and thus obtained an estimate of the maximum distance between an epitope and the center of the corresponding gold particle. This distance was estimated at $26-30 \mathrm{~nm}$, because background levels of gold particle density were reached $26-30 \mathrm{~nm}$ peripheral to the margin of the test bodies (Fig. 7B). For GluR2/3, this implies that virtually all $15 \mathrm{~nm}$ gold particles can be accounted for by epitopes localized within the postsynaptic density or in close contiguity with this (Fig. $5 A$ ), supporting the observations in silverenhanced preparations (Fig. $2 A$ ). As expected, the use of secondary IgG coupled to $15 \mathrm{~nm}$ gold (as in Fig. $5 A$ ) produces a wider radial spread of particles than the silver enhancement procedure, which is based on secondary Fab fragments and $1.4 \mathrm{~nm}$ gold particles (Fig. 2).

\section{GluR1}

The antibody to GluR1 (Ab 9, same as Ab 7) (Wenthold et al., 1992) failed to produce an immunogold signal in the synaptic region of the inner hair cells (Fig. $8 A$ ). This was not because of methodological imperfections, because distinct GluR1 immuno- 

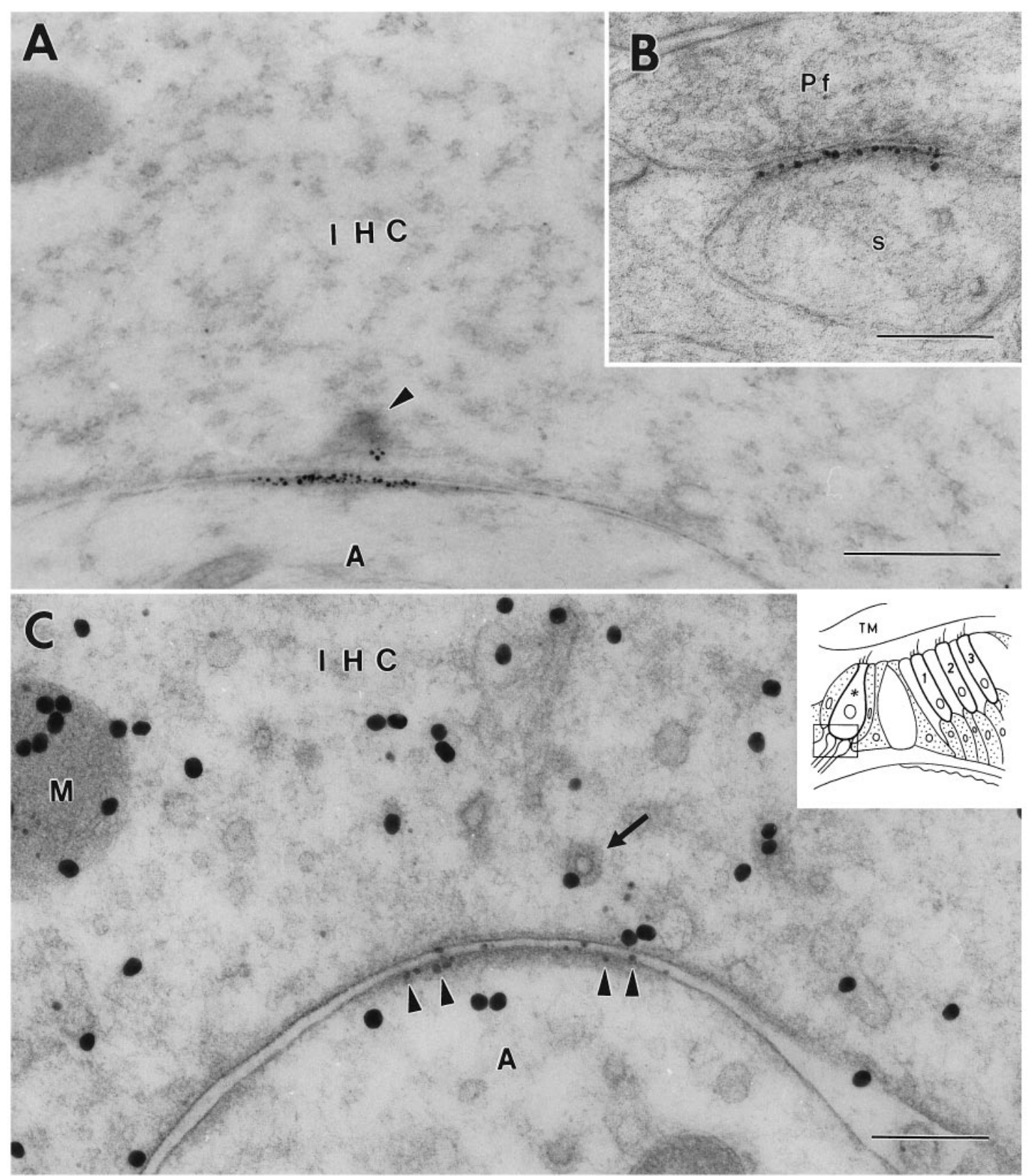

Figure 2. Immunoreactivity for GluR2/3 at an inner hair cell $(I H C)$ synapse in the organ of Corti $(A, C)$ and a parallel fiber $(P f)$ to Purkinje cell synapse in the cerebellum $(B)$. The $1.4 \mathrm{~nm}$ gold particles were made visible by silver enhancement. The section in $A$ is not at the center of the synapse because the synaptic body (arrowhead) is cut near its periphery. $C$, Double immunolabeling. After demonstration of GluR2/3 by silver intensification (small particles, arrowheads), the sections were immunolabeled for glutamate (30 $\mathrm{nm}$ gold particles). Some of the large particles appear to be associated with vesicles (arrow) and with mitochondria $(M)$. Inset shows a diagram of the organ of Corti. Frame indicates area represented in this and subsequent illustrations. Asterisk, Inner hair cell contacted by afferent dendrites; $1-3$, the three rows of outer hair cells. $s$, Purkinje cell spine; $A$, afferent dendrite; $T M$, tectorial membrane. $A, B$, Fixative No. 1 (see Materials and Methods). $C$, Fixative No. 2. Freeze substitution. Scale bars: $0.5 \mu \mathrm{m}$ in $A, 0.2 \mu \mathrm{m}$ in $B$ and $C$.

labeling was observed in accompanying sections of the hippocampus (Fig. $8 B$; same fixative and embedding).

\section{Colocalization of GluR2/3 and GluR4}

Because immunolabeling was obtained with antibodies to GluR2/3 as well as to GluR4, the question arose whether these receptor isoforms are colocalized in the same synapses. Direct evidence for this was provided by double labeling with two different gold particle sizes (Fig. 9A,B). The same double-labeling procedure failed to produce labeling in the synaptic region of the outer hair cells (Fig. 9C), and no labeling was observed at this site with the antibody to GluR1.

\section{DISCUSSION}

The inner hair cell synapse as an experimental model

The aim of the present study was to elucidate the spatial organization of AMPA receptors at the afferent synaptic contact established by the inner hair cells of the organ of Corti. This represents a uniform type of synapse that can be recognized unequivocally by 

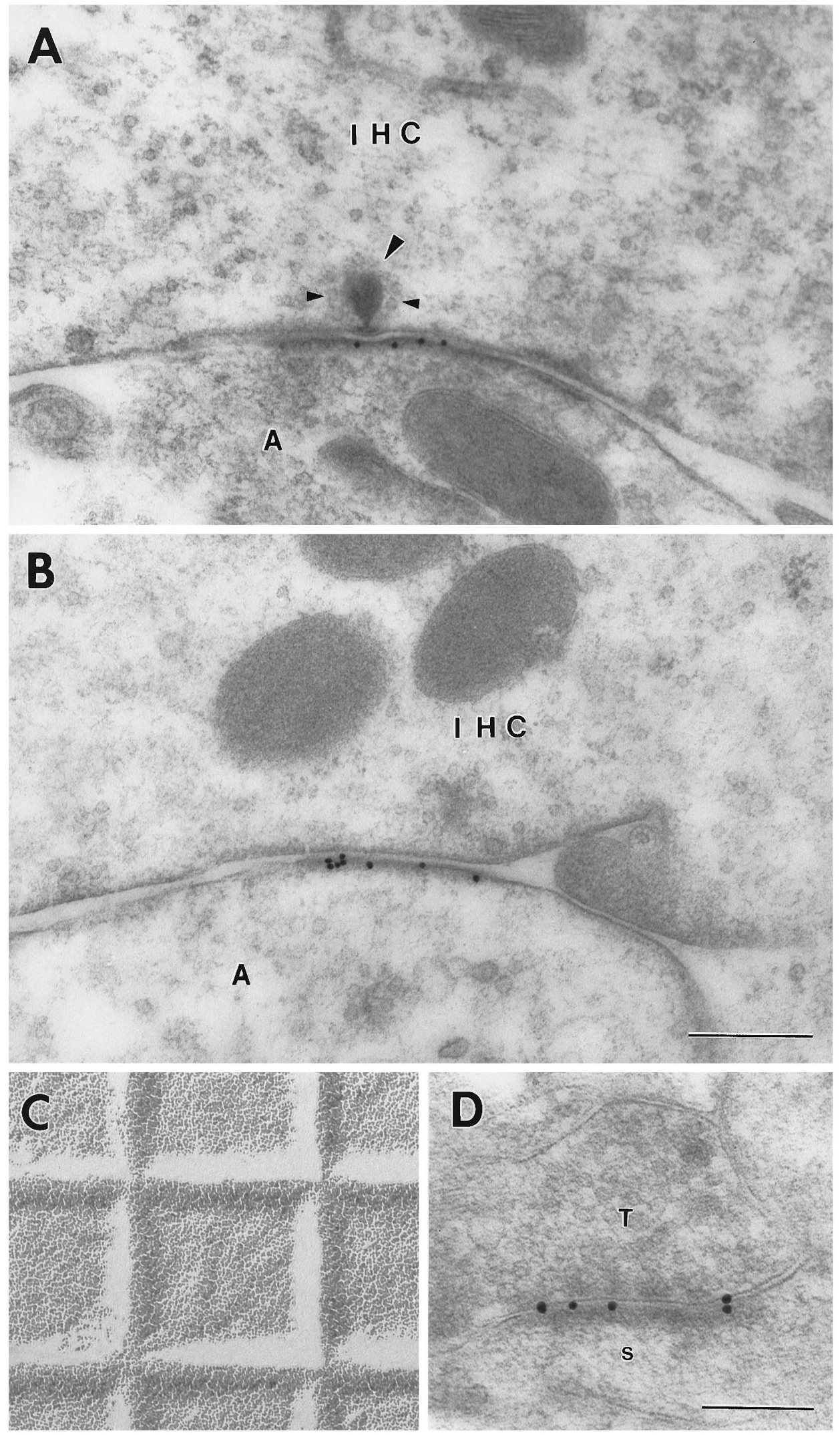

Figure 3. Immunoreactivity for GluR2/3 at an inner hair cell synapse $(A, B)$ and at a hippocampal synapse $(D)$ as demonstrated by $15 \mathrm{~nm}$ gold particles. Large arrowhead, Synaptic body surrounded by synaptic vesicles (small arrowheads). C, Electron micrograph of grid (square width $0.4629 \mathrm{~mm}$ ) for accurate calibration (same magnification as $A$ and $B) . T$, Presynaptic terminal in stratum oriens of CA1; $s$, postsynaptic spine. Other abbreviations as in Figure 1. Fixative No. 2; freeze substitution. Scale bars: $0.3 \mu \mathrm{m}$ in $A-C, 0.2 \mu \mathrm{m}$ in $D$. 

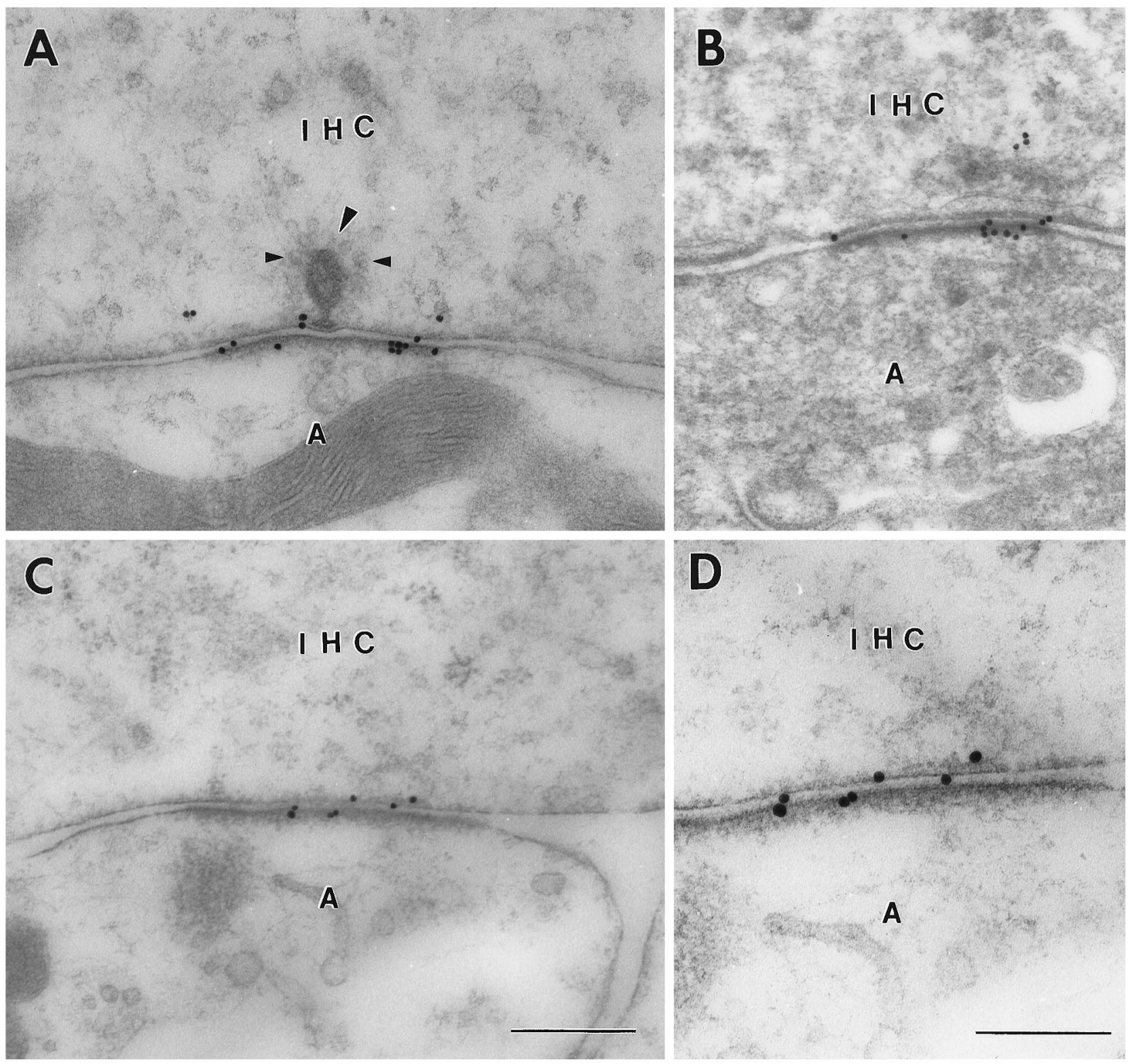

Figure 4. Immunoreactivity for GluR4 at inner hair cell synapses as demonstrated by $15 \mathrm{~nm}$ immunogold particles using different fixatives and tissue preparation methods. $A, C, D$, Fixative No. 2, freeze substitution. $B$, Fixative No. 4, method of Phend et al. (1995). Note that some gold particles are associated with the presynaptic membrane. Large arrowhead, Synaptic body surrounded by synaptic vesicles (small arrowheads). $D$, Enlargement of $C$. Abbreviations as in Figure 1. Scale bars: $0.3 \mu \mathrm{m}$ in $A-C, 0.2 \mu \mathrm{m}$ in $D$.

its morphological features (Friedmann and Ballantyne, 1984). There is strong evidence that glutamate is used as a transmitter at this synapse (for review, see Eybalin, 1993; Kataoka and Ohmori, 1994). In further support of this, we could presently demonstrate, by double labeling, glutamate-enriched hair cells (Altschuler et al., 1989; Usami et al., 1992) in direct apposition to glutamate receptors. A special feature of the inner hair cell synapse is that it is one of the few types of synapses in which the approximate position of the center can be defined morphologically, by the presence of a synaptic body (Friedmann and Ballantyne, 1984). This greatly facilitates analysis of the tangential distribution of receptors (which would otherwise require serial sections) and also may be a useful feature in modeling of synaptic events. Thus, it has been proposed that the synaptic body plays a central role in exocytotic transmitter release (Parsons et al., 1994) and that it represents the site where most exocytotic events occur (Furukawa et al., 1982).

Previous physiological and pharmacological data have suggested that the spiral ganglion cells, which constitute the postsynaptic element of the inner hair cell synapse, are equipped with AMPA receptors. Infusion of quisqualate into the perilymph increases the unit activity of spiral ganglion neurons (Jenison and Bobbin, 1985), and perilymphatic perfusion of AMPA suppresses significantly the compound auditory nerve action potential (Puel et al., 1991). Further, patch-clamp studies have revealed the presence of functional AMPA receptors in isolated spiral ganglion cells (Nakagawa et al., 1991b). Studies based on in situ hybridization and light microscopic immunocytochemistry have supported the above data and have demonstrated that the spiral ganglion cells express AMPA receptor mRNAs, as well as the correspond- 

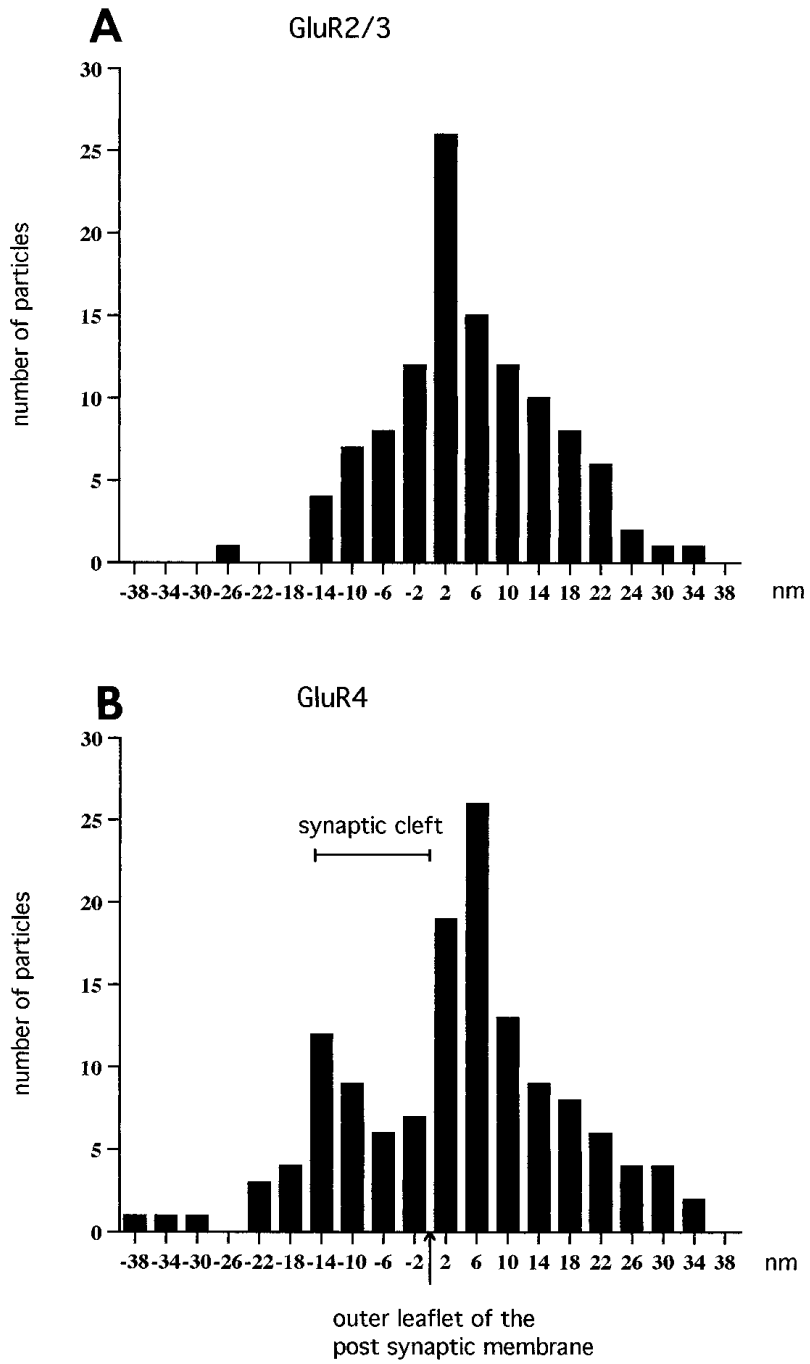

Figure 5. Histograms showing the radial distribution of gold particles representing GluR2/3 $(A)$ and GluR4 $(B)$ at inner hair cell synapses. The distances between the centers of the $15 \mathrm{~nm}$ gold particles and the outer leaflet of the postsynaptic membrane were grouped into bins $4 \mathrm{~nm}$ wide. The values along the abscissa indicate bin centers. Minus signs indicate direction of the presynaptic element. The data were pooled from 25 synapses $(A)$ and 23 synapses $(B)$. The particles signaling GluR2/3 $(A)$ showed essentially a normal distribution with an average of $4.9 \mathrm{~nm}$ (SEM 1.0). The histogram of GluR4 distribution was broader than that of GluR2/3 and displayed two peaks. The extent of the synaptic cleft is indicated.

Table 1. Radial distributions of GluR2/3 and GluR4

Gold particles

Gold particles signaling GluR4 signaling GluR2/3

Presynaptic to midpoint of cleft $32(23.7 \%) \quad 12(10.6 \%)$

Postsynaptic to midpoint of cleft $103(76.3 \%) \quad 101(89.4 \%)$

To compare the distributions of gold particles in sections labeled with either the GluR4 or GluR2/3 antiserum, the gold particles were categorized into two groups based on their localization with respect to the midpoint of the synaptic cleft set at 7.5 $\mathrm{nm}$ from the outer leaflet of the postsynaptic membrane. Compared with particles signaling GluR2/3, particles signaling GluR4 were significantly enriched presynaptic to the cleft midline. Chi square test, $p=0.0072$ (no. of synapses studied $=25$ ). Note that because of the distance between epitope and gold particles (Fig. 7), some particles derived from a postsynaptic epitope will end up presynaptic to the cleft midline. The distribution of gold particles signaling GluR2/3 is thus consistent with an exclusively postsynaptic localization of this receptor subunit.
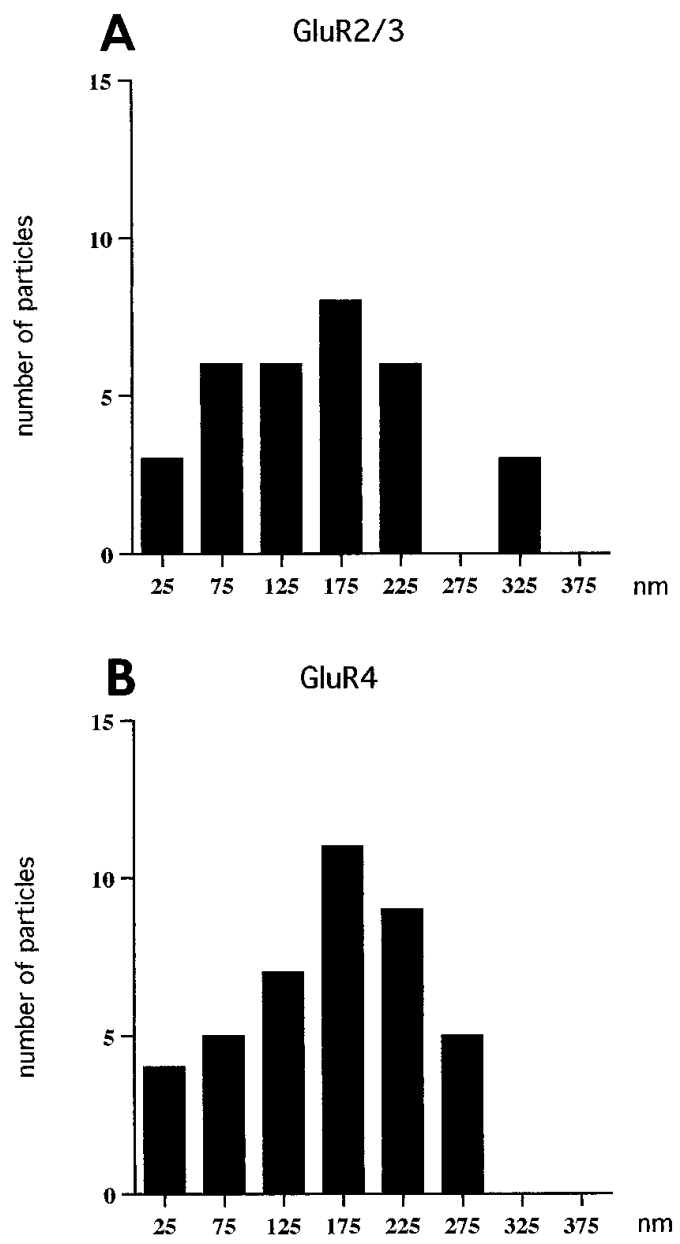

Figure 6. Histogram showing the tangential distribution of gold particles $(15 \mathrm{~nm})$ representing GluR2/3 $(A)$ and GluR4 $(B)$ in the postsynaptic membrane of inner hair cell synapses. Zero is defined as the point opposite the center of the synaptic body. The tangential extent of the synapse was set at $100 \%$, and the synaptic body was localized at $50.9 \pm$ $6.3 \%$ (mean $\pm \mathrm{SD}, n=25$ ), i.e., near the middle of the synapse. Only synapses with distinct synaptic bodies cut at their approximate centers were included in the analysis (13 synapses for GluR2/3 and 12 for GluR4). Bin width, $50 \mathrm{~nm}$. Values along the $x$-axis indicate centers of bins. Gold particles were omitted if situated $>28 \mathrm{~nm}$ away from the cytoplasmic aspect of the postsynaptic membrane, i.e., particles, which according to Figure 7, could not represent postsynaptic receptors with a localization corresponding to the position of the peak in Figure $5 \mathrm{~A}$. The distance (mean $\pm \mathrm{SD}, n=25$ ) between the synaptic body and the lateralmost gold particle was $196 \pm 64 \mathrm{~nm}$ (maximum $301 \mathrm{~nm}$ ) compared with a radius of the postsynaptic density of $260 \pm 44 \mathrm{~nm}$ (range 157-382).

ing proteins (Ryan et al., 1991; Safieddine and Eybalin, 1992; Kuriyama et al., 1994; Niedzielski and Wenthold, 1995; Usami et al., 1995).

\section{Postsynaptic arrangement of AMPA receptors}

The present investigation provides detailed information on the organization of the AMPA receptors in the inner hair cell synapse. Electron-dense particles were used as markers to achieve optimum resolution and quantifiability. A common limiting factor in studies based on this kind of approach is the sensitivity that often permits only very low particle counts. In the present study, a high sensitivity was obtained by using immunolabeling techniques that had been systematically modified for high-labeling efficiency, and by using tissue specimens that had been prepared 


\section{A}
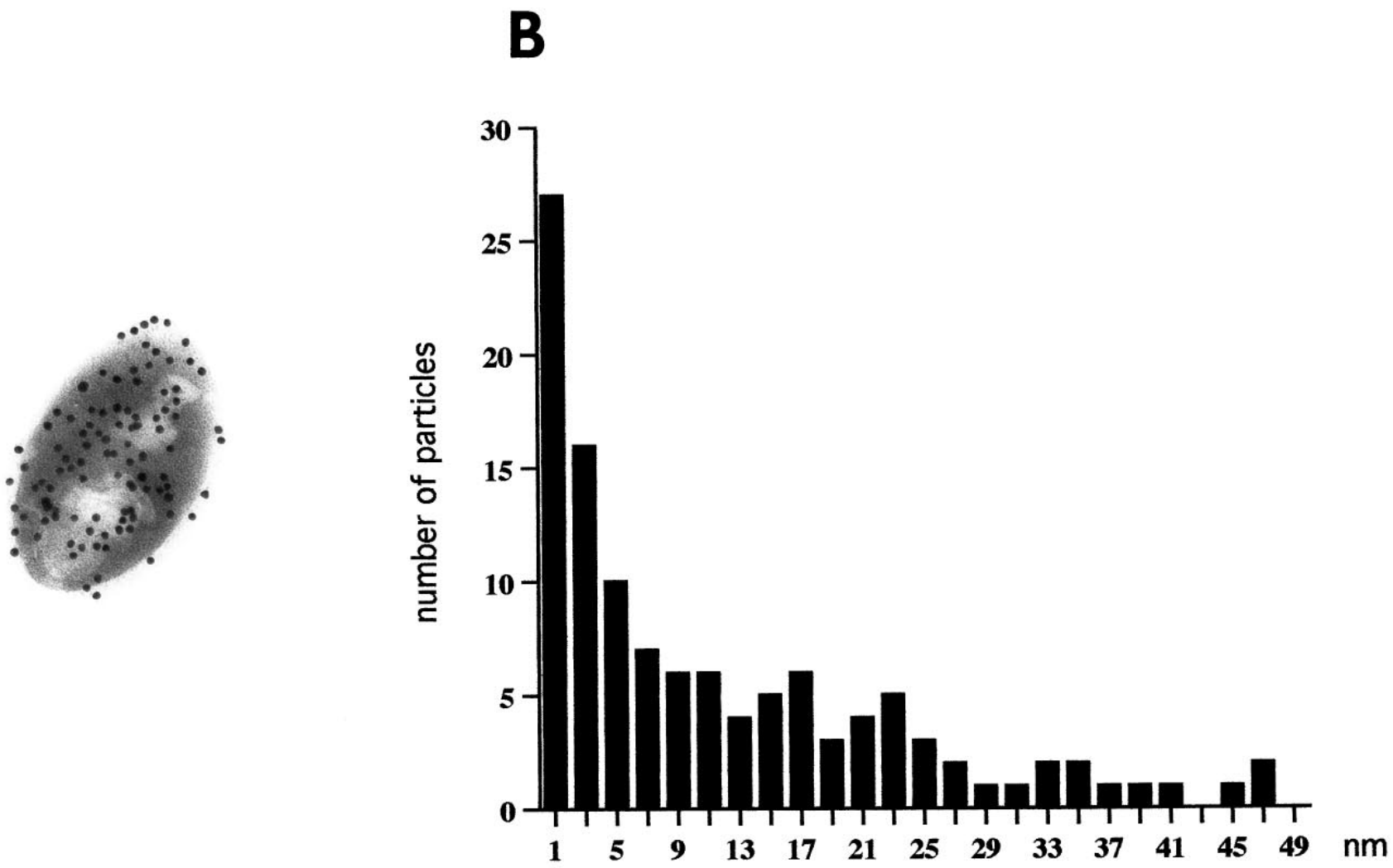

Figure 7. Lateral resolution of current immunogold procedure ( $15 \mathrm{~nm}$ gold particles). Values along the $x$-axis in $B$ denote distance from centers of gold particles to the margin of antigen-containing bodies $(A)$. Particles were included for analysis only where the adjacent margin was sharply defined. Background level of labeling is reached $\sim 28 \mathrm{~nm}$ off the bodies. Bin width, $2 \mathrm{~nm}$ (midpoint indicated). The data were based on the analysis of 30 bodies containing glutaraldehyde-fixed L-aspartate as a model antigen. The aspartate antibody (No. 18) has been characterized (Zhang et al., 1990). Scale bar, $0.3 \mu \mathrm{m}$.
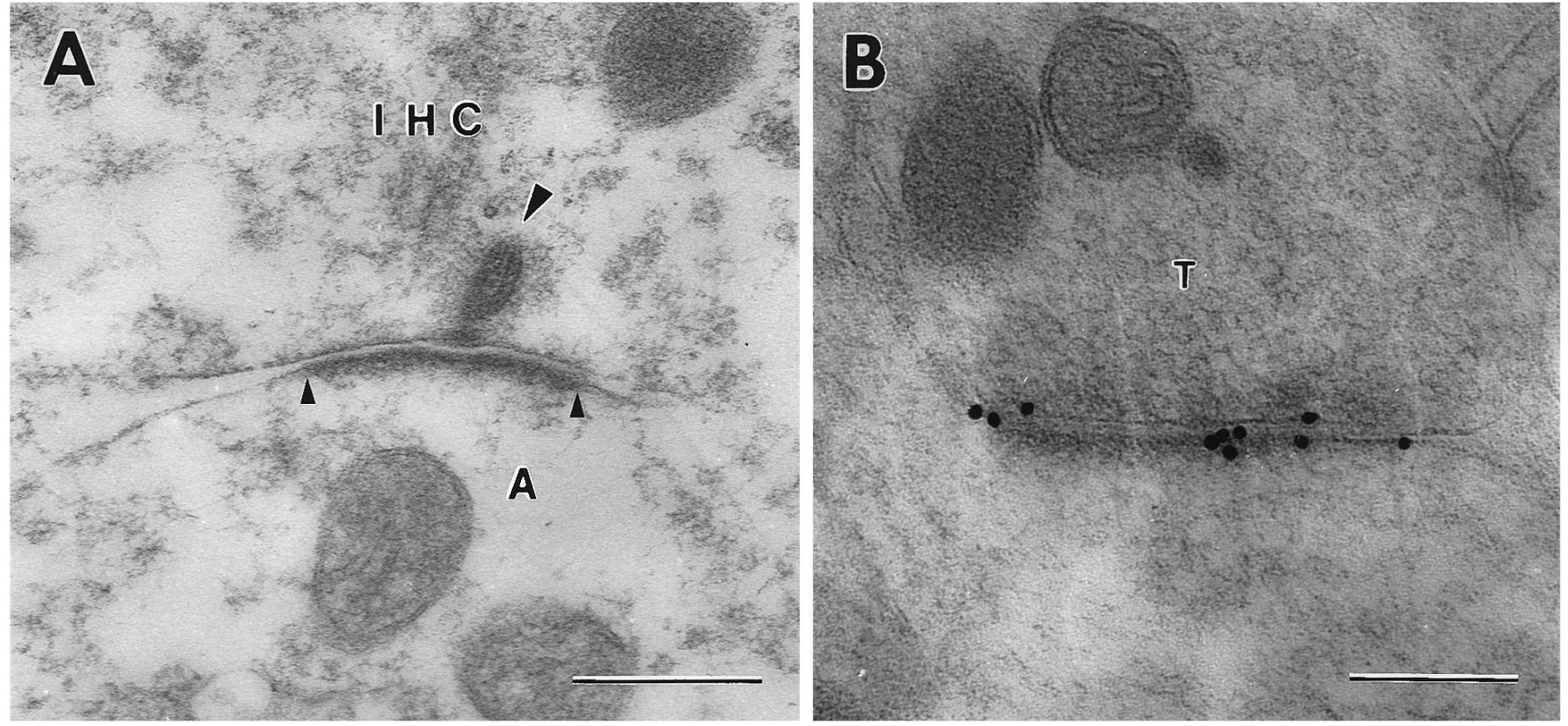

Figure 8. Section of an inner hair cell synapse $(A)$ and of a hippocampal synapse $(B)$ incubated in the same drop of GluR1 antiserum. Only the latter synapse is labeled. Large arrowhead, Synaptic body. Small arrowheads indicate extent of postsynaptic specialization. $T$, Presynaptic terminal in stratum oriens of CA1. Other abbreviations as in Figure 1. Fixative No. 1; freeze substitution. Scale bars: $0.3 \mu \mathrm{m}$ in $A, 0.2 \mu \mathrm{m}$ in $B$. 

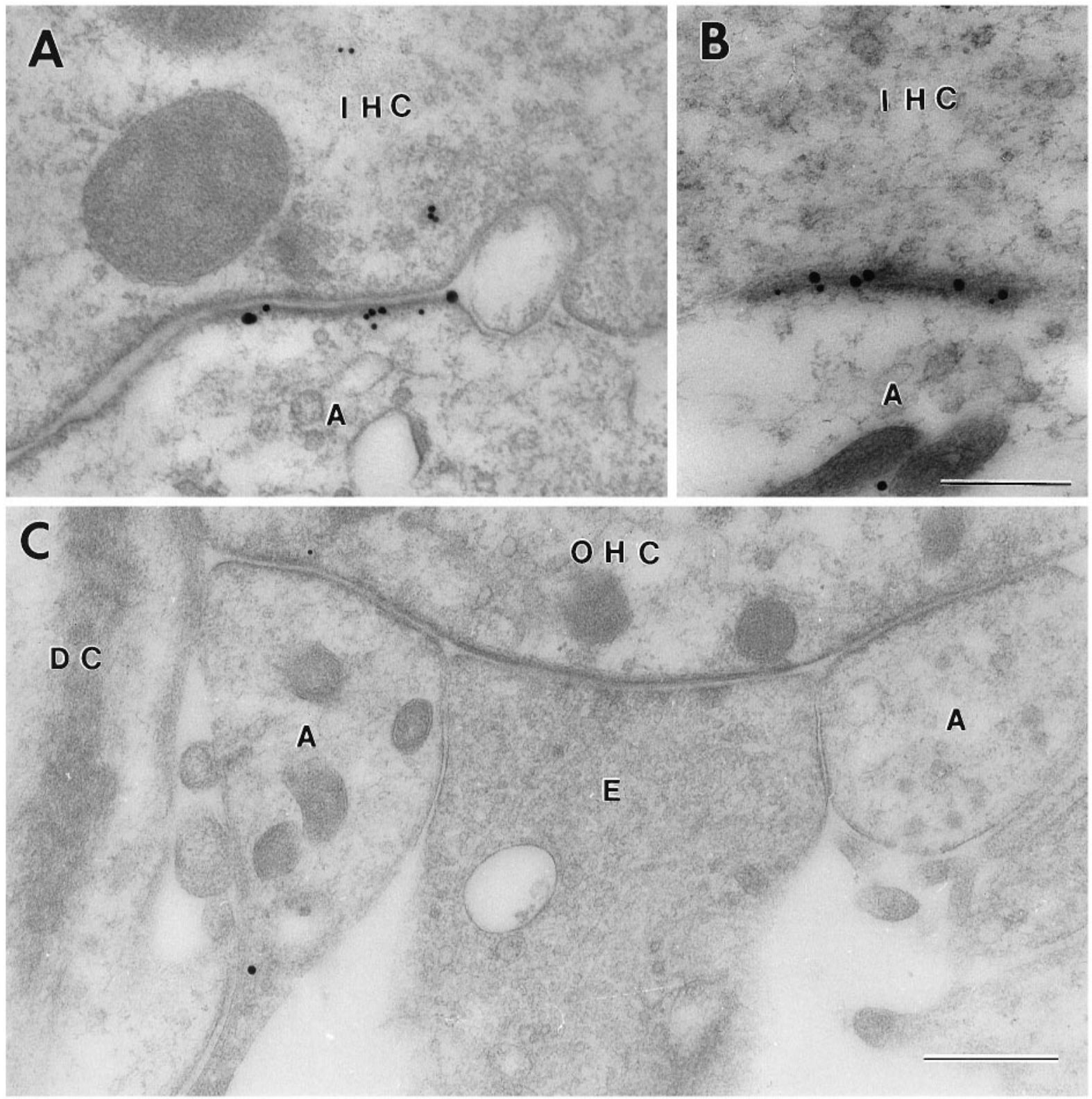

Figure 9. Double-labeled ultrathin sections from the rat organ of Corti. $A, B$, Inner hair cells $(I H C)$. $A$, GluR2/3, $30 \mathrm{~nm}$ gold particles; GluR4, $15 \mathrm{~nm}$ gold particles. $B$, GluR2/3, $15 \mathrm{~nm}$ gold particles; GluR4, $30 \mathrm{~nm}$ gold particles. Fixative No. 2. $C$, No immunoreactivity was detected in the synaptic region of the outer hair cells $(O H C)$. Same combination of antibodies as in $B . D C$, Deiters cell; E, efferent nerve terminal. Other abbreviations as in Figure 1. Fixative No. 2. Freeze substitution. Scale bars: $0.3 \mu \mathrm{m}$ in $A$ and $B, 0.5 \mu \mathrm{m}$ in $C$.

by freeze substitution and Lowicryl embedding. The latter procedure offers a better preservation of tissue antigens than standard embedding procedures (van Lookeren Campagne et al., 1991).

Our findings suggest that the postsynaptic GluR2/3 and GluR4 subunits are restricted to a disk with a radius up to $300 \mathrm{~nm}$ and with a center aligned with the synaptic body. The area of receptor distribution coincides closely with the postsynaptic density and immunolabeling extended to its very edge (Figs. $3 B, 4 A, B$ ). (The discrepancy between the radius of the postsynaptic density and the distribution area of gold particles as calculated in Fig. 6 can be accounted for by a variable labeling efficiency in the sample of synapses.) A preferential localization of AMPA receptors at postsynaptic densities also has been reported for synapses in the CNS, using approaches similar to those used here (Nusser et al., 1994; Baude et al., 1995; Phend et al., 1995). In the inner hair cell synapse, the GluR2/3 and GluR4 subunits are colocalized to the same postsynaptic densities and show a similar tangential distribution, compatible with their being components of heterooligomeric receptors (Boulter et al., 1990; Keinänen et al., 1990; Nakanishi et al., 1990; Wenthold et al., 1992). The higher labeling density laterally than centrally in the synapse suggests that the receptor concentration is highest where the glutamate concentration is attenuated because of lateral diffusion (assuming that release occurs preferentially at the synaptic body). Given the relatively low affinity of the AMPA receptor for glutamate (Clements et al., 1992), this arrangement may promote an even density of open receptor channels along the postsynaptic membrane after an exocytotic event. The nonuniform postsynaptic distribution of AMPA receptors reported here does not appear to be a feature common to all synapses. Thus, immunogold particles signaling 
AMPA receptors were evenly distributed along the membrane specializations postsynaptic to cerebellar parallel fiber terminals (Nusser et al., 1994).

For GluR2/3, the distribution of gold particles is consistent with the subunit(s) being associated exclusively with the postsynaptic membrane. Judged from the peak of the gold particle distribution (Shida, 1991), the epitopes are concentrated close to its cytoplasmic aspect. Although the resolution of the present procedure does not permit firm conclusions on this point, our results are compatible with the revised model of the transmembrane topology of the AMPA receptors (Hollmann et al., 1994; Baude et al., 1995; Bennett and Dingledine, 1995), which holds that the C-terminal end of the receptor protein is intracellular. Pre-embedding immunogold cytochemistry with antibodies to GluR4 has provided further evidence for this (Baude et al., 1995).

Our failure to obtain data supporting an involvement of GluR1 receptors in hair cell neurotransmission is in line with previous immunocytochemical and in situ hybridization results (Ryan et al., 1991; Safieddine and Eybalin, 1992; Kuriyama et al., 1994; Niedzielski and Wenthold, 1995; Usami et al., 1995). It should be noted that the GluR1 subunit is not an obligatory component of functional AMPA receptors (Boulter et al., 1990).

\section{Evidence for presynaptic GluR4 receptors}

Although our data indicated a similar distribution of GluR4 and GluR2/3 along the mediolateral extent of the postsynaptic density, the radial distribution of gold particles was suggestive of an additional but smaller pool of GluR4 associated with the presynaptic membrane. This would agree with recent physiological investigations of type I vestibular hair cells of guinea pig (Devau et al., 1993). These cells appear to be equipped with AMPA receptors, as well as other types of glutamate receptor that may serve as autoreceptors involved in the control of synaptic transmission. In contrast, glutamate autoreceptors in the CNS are typically insensitive to AMPA (Chittajallu et al., 1996). However, Baude et al. (1995) reported, but failed to illustrate, some presynaptic immunolabeling for GluR4 in the rat hippocampus.

\section{Outer hair cells}

There are conflicting data in the literature concerning the possible involvement of AMPA receptors in the chemical transmission of outer hair cells. Niedzielski and Wenthold (1995) detected AMPA receptor mRNA and the corresponding proteins in type II and type I ganglion cells, which innervate the outer and inner hair cells, respectively, whereas Safieddine and Eybalin (1992) found AMPA receptor mRNA in the latter, but not in the former type of ganglion cell. In an immunofluorescence study, Kuriyama et al. (1994) described a patchy labeling for GluR4 in the outer hair cell region, which was interpreted as reflecting the presence of this receptor at the bases of the hair cells. Our study suggests that if GluR4 occurs in the synaptic region of the outer hair cells, its level of expression must be far lower than at the inner hair cells.

The differences observed here between the outer and inner hair cell synapses in regard to their receptor profile are intriguing from a functional point of view. There is no evidence that the afferent fibers contacting the outer hair cells respond to acoustic stimulation (Patuzzi and Robertson, 1988), so one cannot exclude that this synapse is functionally silent. The outer hair cells are unlikely to be depolarized beyond $-60 \mathrm{mV}$ even on maximum sound stimulation (Patuzzi and Robertson, 1988). This would not be sufficient to activate the voltage-dependent $\mathrm{Ca}^{2+}$ channels, whose threshold is more positive than $-30 \mathrm{mV}$ (Nakagawa et al., 1991a).
Opening of the latter channels is assumed to be necessary for transmitter release. In agreement, ultrastructural studies have suggested that the outer hair cells exhibit a low rate of vesicle recycling compared with the inner hair cells (Siegel and Brownell, 1986). The present observations are likely to reflect the significant functional differences between these two types of receptor cell.

\section{Conclusion}

The inner hair cell synapse can be regarded as a glutamatergic synapse with an anatomically defined site of exocytotic release. Assuming release at the synaptic body, the quantum of glutamate will face postsynaptic receptors composed of GluR2/3 and GluR4 subunits and extending laterally for up to $300 \mathrm{~nm}$ in each direction with a peak concentration in the peripheral zone of the postsynaptic density and a trough centrally, near the release site. A few AMPA receptors containing GluR4 subunits, but not GluR2/3 subunits, also may be present presynaptically. AMPA receptors are distributed throughout the postsynaptic density, but appear to be very scarce lateral to the synaptic cleft. The present data and recent observations in the CNS (Baude et al., 1995) are indicative of a highly selective targeting of AMPA receptor subunits to synaptic membranes.

\section{REFERENCES}

Altschuler RA, Sheridan CE, Horn JW, Wenthold RJ (1989) Immunocytochemical localization of glutamate immunoreactivity in the guinea pig cochlea. Hear Res 42:167-174.

Anniko M, Lundquist P-G (1980) Temporal bone morphology after systemic arterial perfusion or intralabyrinthine in situ immersion. 1. Hair cells of the vestibular organs and the cochlea. Micron 11:73-83.

Baude A, Nusser Z, Molnár E, McIlhinney RAJ, Somogyi P (1995) High-resolution immunogold localization of AMPA type glutamate receptor subunits at synaptic and non-synaptic sites in rat hippocampus. Neuroscience 69:1031-1055.

Bennett JA, Dingledine R (1995) Topology profile for a glutamate receptor: three transmembrane domains and a channel-lining reentrant membrane loop. Neuron 14:373-384.

Boulter J, Hollmann M, O'Shea-Greenfield A, Hartley M, Deneris E, Maron C, Heinemann S (1990) Molecular cloning and functional expression of glutamate receptor subunit genes. Science 249:1033-1037.

Chaudhry FA, Lehre KP, van Lookeren Campagne M, Ottersen OP, Danbolt NC, Storm-Mathisen J (1995) Glutamate transporters in glial plasma membranes: highly differentiated localizations revealed by quantitative ultrastructural immunocytochemistry. Neuron 15:711-720.

Chittajallu R, Vignes M, Dev KK, Barnes JM, Collingridge GL, Henley JM (1996) Regulation of glutamate release by presynaptic kainate receptors in the hippocampus. Nature 379:78-81.

Clements JD, Lester RAJ, Tong G, Jahr CE, Westbrook GL (1992) The time course of glutamate in the synaptic cleft. Science 258:1498-1501.

Devau G, Lehouelleur J, Sans A (1993) Glutamate receptors on type I vestibular hair cells of guinea pig. Eur J Neurosci 5:1210-1217.

Edwards FA (1995a) LTP_a structural model to explain the inconsistencies. Trends Neurosci 18:250-255.

Edwards FA (1995b) Anatomy and electrophysiology of fast central synapses lead to a structural model for long-term potentiation. Physiol Rev 75:759-787.

Ericson A-C, Blomqvist A, Craig AD, Ottersen OP, Broman J (1995) Evidence for glutamate as neurotransmitter in trigemino- and spinothalamic tract terminals in the nucleus submedius of cats. Eur J Neurosci 7:305-317.

Eybalin M (1993) Neurotransmitters and neuromodulators of the mammalian cochlea. Physiol Rev 73:309-373.

Friedmann I, Ballantyne J (1984) Ultrastructural atlas of the inner ear. London: Butterworths.

Furukawa T, Kuno M, Matsuura S (1982) Quantal analysis of a decremental response at hair cell-afferent fibre synapses in the goldfish sacculus. J Physiol (Lond) 322:181-195.

Hashimoto S, Kimura RS, Takasaka T (1990) Computer-aided threedimensional reconstruction of the inner hair cells and their nerve endings in the guinea pig cochlea. Acta Otolaryngol (Stockh) 109:228-234. 
Hjelle OP, Chaudhry FA, Ottersen OP (1994) Antisera to glutathione: characterization and immunocytochemical application to the rat cerebellum. Eur J Neurosci 6:794-804.

Hollmann M, Maron C, Heinemann S (1994) N-glycosylation site tagging suggests a three transmembrane domain topology for the glutamate receptor GluR1. Neuron 13:1331-1343.

Jenison GL, Bobbin RP (1985) Quisqualate excites spiral ganglion neurons of the guinea pig. Hear Res 20:261-265.

Ji Z, Aas J-E, Laake J, Walberg F, Ottersen OP (1991) An electron microscopic immunogold analysis of glutamate and glutamine in terminals of rat spinocerebellar fibers. J Comp Neurol 307:296-310.

Kataoka Y, Ohmori H (1994) Activation of glutamate receptors in response to membrane depolarization of hair cells isolated from chick cochlea. J Physiol (Lond) 477:403-414.

Keinänen K, Wisden W, Sommer B, Werner P, Herb A, Verdoorn TA, Sakmann B, Seeburg PH (1990) A family of AMPA-selective glutamate receptors. Science 249:556-560.

Kuriyama H, Jenkins O, Altschuler RA (1994) Immunocytochemical localization of AMPA selective glutamate receptor subunits in the rat cochlea. Hear Res 80:233-240.

Nakagawa T, Kakehata S, Akaike N, Komune S, Takasaka T, Uemura T (1991a) Calcium channel in isolated outer hair cells of guinea pig cochlea. Neurosci Lett 125:81-84.

Nakagawa T, Komune S, Uemura T, Akaike N (1991b) Excitatory amino acid response in isolated spiral ganglion cells of guinea pig cochlea. J Neurophysiol 65:715-723.

Nakanishi N, Schneider NA, Axel R (1990) A family of glutamate receptor genes: evidence for the formation of heteromultimeric receptors with distinct channel properties. Neuron 5:569-581.

Niedzielski AS, Wenthold RJ (1995) Expression of AMPA, kainate, and NMDA receptor subunits in cochlear and vestibular ganglia. J Neurosci 15:2338-2353.

Nusser Z, Mulvihill E, Streit P, Somogyi P (1994) Subsynaptic segregation of metabotropic and ionotropic glutamate receptors as revealed by immunogold localization. Neuroscience 61:421-427.

Ottersen OP (1987) Postembedding light- and electron microscopic immunocytochemistry of amino acids: description of a new model system allowing identical conditions for specificity testing and tissue processing. Exp Brain Res 69:167-174.

Ottersen OP, Zhang N, Walberg F (1992) Metabolic compartmentation of glutamate and glutamine: morphological evidence obtained by quantitative immunocytochemistry in rat cerebellum. Neuroscience 46:519-534.

Parsons TD, Lenzi D, Almers W, Roberts WM (1994) Calcium-triggered exocytosis and endocytosis in an isolated presynaptic cell: capacitance measurements in saccular hair cells. Neuron 13:875-883.

Patuzzi R, Robertson D (1988) Tuning in the mammalian cochlea. Physiol Rev 68:1009-1082.

Petralia RS, Wenthold RJ (1992) Light and electron immunocytochemical localization of AMPA-selective glutamate receptors in the rat brain. J Comp Neurol 318:329-354.

Phend KD, Rustioni A, Weinberg RJ (1995) An osmium-free method of epon embedment that preserves both ultrastructure and antigenicity for post-embedding immunocytochemistry. J Histochem Cytochem 43:283-292.

Puel J-L, Pujol R, Ladrech S, Eybalin M (1991) $\alpha$-Amino-3-hydroxy-5methyl-4-isoxazole propionic acid electrophysiological and neurotoxic effects in the guinea pig cochlea. Neuroscience 45:63-72.

Rothstein JD, Martin L, Levey AI, Dykes-Hoberg M, Jin L, Wu D, Nash N, Kuncl RW (1994) Localization of neuronal and glial glutamate transporters. Neuron 13:713-725.

Ryan AF, Brumm D, Kraft M (1991) Occurrence and distribution of non-NMDA glutamate receptor mRNAs in the cochlea. NeuroReport 2:643-646.

Safieddine S, Eybalin M (1992) Co-expression of NMDA and AMPA/ kainate receptor mRNAs in cochlear neurones. NeuroReport 3:1145-1148.

Shida H (1991) A study of protein A-gold resolution for immunoelectron microscopy. J Electron Microsc Tech 18:291-295.

Siegel JH, Brownell WE (1986) Synaptic and Golgi membrane recycling in cochlear hair cells. J Neurocytol 15:311-328.

Somogyi P, Halasy K, Somogyi J, Storm-Mathisen J, Ottersen OP (1986) Quantification of immunogold labelling reveals enrichment of glutamate in mossy and parallel fiber terminals in cat cerebellum. Neuroscience 19:1045-1050.

Usami S, Osen KK, Zhang N, Ottersen OP (1992) Distribution of glutamate-like and glutamine-like immunoreactivities in the rat organ of Corti: a light microscopic and semiquantitative electron microscopic analysis with a note on the localization of aspartate. Exp Brain Res 91:1-11.

Usami S, Matsubara A, Fujita S, Shinkawa H, Hayashi M (1995) NMDA (NMDAR1) and AMPA-type (GluR2/3) receptor subunits are expressed in the inner ear. NeuroReport 6:1161-1164.

van Lookeren Campagne M, Oestreicher AB, van der Krift TP, Gispen WH, Verkleij AJ (1991) Freeze-substitution and Lowicryl HM20 embedding of fixed rat brain: suitability for immunogold ultrastructural localization of neural antigens. J Histochem Cytochem 39:1267-1279.

Wang B-L, Larsson L-I (1985) Simultaneous demonstration of multiple antigens by indirect immunofluorescence or immunogold staining: novel light and electron microscopical double and triple staining method employing primary antibodies from the same species. Histochemistry 83:47-56.

Wenthold RJ, Yokotani N, Doi K, Wada K (1992) Immunochemical characterization of the non-NMDA glutamate receptor using subunitspecific antibodies. J Biol Chem 267:501-507.

Wersäll J (1956) Studies on the structure and innervation of the sensory epithelium of the cristae ampullares in the guinea pig. Acta Otolaryngol Suppl (Stockh) 126:185.

Zhang N, Walberg F, Laake JH, Meldrum BS, Ottersen OP (1990) Aspartate-like and glutamate-like immunoreactivities in the inferior olive and climbing fibre system: a light microscopic and semiquantitative electron microscopic study in rat and baboon (Papio anubis). Neuroscience 38:61-80. 